\title{
Atmospheric deposition of nutrients in a coastal maquis ecosystem of northeastern Greece
}

\author{
M. Arianoutsou \\ Division of Ecology, Department of Biology, University of Thessaloniki, U.P. Box 119, GR-54006 Thessaloniki, Greece
}

\begin{abstract}
The deposition of nutrients N, P, Ca, $\mathrm{Mg}, \mathrm{Na}$ and $\mathrm{K}$ from the atmosphere on a coastal maquis ecosystem was studied over a 12-month period (1981-1982). The annual precipitation during that period was $1065 \mathrm{~mm}$. Nutrient input was estimated as $5.72,0.24,30.31,3.40,23.99$ and $1616 \mathrm{~kg} \mathrm{ha}^{-1}$ year $^{-1}$ for $\mathrm{N}, \mathrm{P}, \mathrm{Ca}, \mathrm{Mg}, \mathrm{Na}$ and $\mathrm{K}$, respectively. Chemical analysis of throughfall showed enrichment for all the nutrients studied. It was concluded that nutrient input from bulk precipitation is an important contribution to nutrient cycling of the Greek maquis ecosystem.
\end{abstract}

Key words: Nutrients - Precipitation - Throughfall - Maquis - Greece

\section{Introduction}

Although the atmosphere has Jong been recognized as a source of chemicals (Tamm 1958), only recently have biologists stressed its role in the biogeochemical cycles of terrestrial ecosystems (Bormann and Likens 1967; Guthrie et al. 1978; Schlesinger and Hasey 1980; Feller 1981; Schlesinger et al. 1982; Brown et al. 1984). Mediterraneantype ecosystems usually occur on nutrient-poor soils. The low plant productivity, the steep or dissected topography and the relatively high erosion rates in most of the areas with mediterranean-type ecosystems (southern California, central Chile, Mediterranean Basin) limit soil development and fertility. In general, soil nutrient deficiencies have been noted in most mediterranean-climate areas (Rundel 1979, among others). Although the deposition of nutrients from the atmosphere is small compared to the annual uptake by the plant community, it is of equal importance if the low soil fertility is considered.
This study deals with nutrient input from precipitation to an area of coastal maquis (evergreen sclerophyllous tall shrub communities) of northeastern Greece. It is part of a broader study on nutrient cycling in this mediterranean-type ecosystem (Arianoutsou 1989; Arianoutsou and Paraskevopoulos, unpublished data), and aims to give some estimation of the geochemical cycle of nutrient imports to the ecosystem.

\section{Study area}

Bulk precipitation (rainfall plus dry fallout) was collected at Stavros, the experimental site $\left(40^{\circ} 39^{\prime} \mathrm{N}, 23^{\circ} 43^{\prime} \mathrm{E}\right.$, ca. $20 \mathrm{~m}$ above sea-level, $60 \mathrm{~km}$ northeast of Thessaloniki, Greece). The vegetation is maquis and the soil is alluvial on biotiticgneiss amphibolitic metamorphic rocks, up to $1 \mathrm{~m}$ deep with $\mathrm{pH}$ of 5.5-6.0 and an organic matter content of $7.5 \%(0-2 \mathrm{~cm}$ depth). The vegetation is $20-25$ years old and is dominated by Quercus coccifera L. (32\% in biomass) and Arbutus unedo L. (15\% in biomass). Other woody species occurring in the area are Phillyrea media L., Erica arborea $\mathrm{L}$., Quercus ilex $\mathrm{L}$. and Cistus sp. The average canopy height is $2.0-2.5 \mathrm{~m}$ and the area has a mediterranean climate.

\section{Materials and methods}

Rainfall was collected at regular 20- to 30-day intervals from two rain-gauges which were maintained at fixed openings throughoul the experimental period. Rainwater as throughfall underneath the canopy was also collected from six rain-gauges placed in groups of three under the dominant shrubs A. unedo and $Q$. coccifera chosen at random.

The rain-gauges $\left(200 \mathrm{~cm}^{2}\right.$ in surface area) were set $0.5 \mathrm{~m}$ above ground-level. They were covered with fibreglass mesh $\left(1 \mathrm{~mm}^{2}\right)$ to prevent contamination from birds, insects and fallen leaves. Each rain-gange funnel was attached to a stainless steel collecting bottle. A preservative $\left(0.5 \mathrm{~cm}^{3} 0.05 \% \mathrm{HgCl}_{2} / 1 \mathrm{~N}\right.$ 


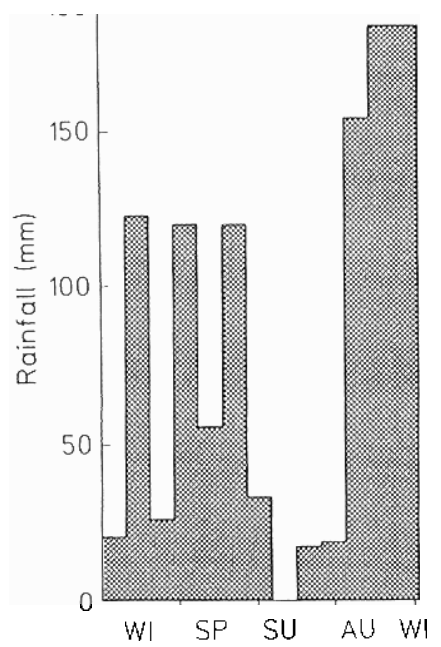

Fig. 1. Total annual precipitation, by season, at Stavros during 1981-1982. WI, winter; SP, spring; SU, summer; AU autumn

$\mathrm{HCl})$ was added to each collecting vessel. The funnels and the bottles were washed with chloroform and double deionized water after each collection.

The water samples were stored below $4^{\circ} \mathrm{C}$ until analysis. They were analysed for cation ( $\mathrm{K}, \mathrm{Na}, \mathrm{Mg}$ and $\mathrm{Ca}$ ) concentrations by atomic absorption spectrophotometry. Total dissolved phosphorus was determined by predigesting all solutions with $\mathrm{HNO}_{3}$ and then determining the resulting orthophosphate in a Technicon Autoanalyser according to the method of Varkey (1966). Total nitrogen was considered to be the sum of nitrate, nitrite and ammonium nitrogen. After Kjeldahl digestion, total nitrogen was determined automatically using a Technicon Autoanalyser (Varley 1966).

\section{Results}

During 1981-1982, total annual precipitation was $1065 \mathrm{~mm}$ and was unevenly distributed in time (Fig. 1). There were two peaks in spring and autumn and two lows in winter and summer. Nutrient inputs during this period ranged from $0.24 \mathrm{~kg} \mathrm{ha}^{-1}$ year $^{-1}$ for phosphorus to $30.31 \mathrm{~kg} \mathrm{ha}^{-1}$ year $^{-1}$ for calcium (Table 1).

There was variation with time in nutrient deposition (Table 1) and concentration (Table 2) which did not show any clear seasonal pattern. Monthly nutrient inputs from rainfall were correlated with monthly precipitation volumes in the case of nitrogen, magnesium, sodium and potassium but not in the case of phosphorus and calcium (Table 3).

The comparison of concentrations of nutrients in rainfall (Table 2) with those in throughfall (Table 5) shows that the rainwater was enriched by its passage through the stand canopy. This enrichment is shown better when using the ratio of throughfall to bulk precipitation inputs based on the concentrations of the nutrients (Table 7). On the other hand, when comparing the deposition of nutrients from rainfall (Table 1) with those from throughfall (Table 4) no such evidence can be seen (see also Table 8). The reason for this difference is that the final volume of rainwater reaching the ground after passing through the canopy is usually less than that in the open. Therefore, even if the concentration of an element in throughfall is higher than that in rainfall, the overall amount of the

Table 1. Monthly deposition of nutrients from precipitation at Stavros, northeastern Grece. The annual deposition of each element is given at the bottom of each respective column

\begin{tabular}{|c|c|c|c|c|c|c|c|}
\hline \multirow[t]{2}{*}{ Collection date } & \multirow{2}{*}{$\begin{array}{l}\text { Precipitation } \\
\text { (mm) }\end{array}$} & \multicolumn{6}{|c|}{ Nutrient deposition (kg ha ${ }^{-1}$ ) } \\
\hline & & $N$ & $P$ & $\mathrm{Ca}$ & $\mathrm{Mg}$ & $\mathrm{Na}$ & $\mathrm{K}$ \\
\hline \multicolumn{8}{|l|}{ 1981: } \\
\hline $\begin{array}{l}\text { December } 16 \\
1982:\end{array}$ & 20.55 & 0.042 & 0.0006 & 0.234 & 0.028 & 0.148 & 0.120 \\
\hline January 19 & 123.30 & 0.295 & 0.1100 & 1.530 & 0.339 & 3.436 & 0.368 \\
\hline February 11 & 26.71 & 0.204 & 0.0010 & 0.412 & 0.065 & 0.286 & $\mathrm{SC}$ \\
\hline March 3 & 80.70 & 0.617 & 0.0056 & 2.794 & 0.199 & 0.930 & 0.424 \\
\hline March 17 & 40.54 & 0.310 & 0.0020 & 0.719 & 0.276 & 0.428 & 0.214 \\
\hline April 6 & 55.98 & 0.264 & 0.0006 & 1.762 & 0.177 & 1.104 & 0.157 \\
\hline May 18 & 120.80 & 0.930 & 0.0902 & 3.820 & 0.678 & 2.219 & 2.527 \\
\hline June 23 & 34.21 & 0.370 & 0.0034 & 1.504 & 0.129 & 0.683 & 0.446 \\
\hline August 23 & 18.75 & 0.555 & 0.0104 & 0.619 & 0.074 & 0.298 & 0.262 \\
\hline September 23 & 19.41 & 0.336 & 0.0110 & 1.138 & 0.079 & 0.243 & 0.249 \\
\hline October 23 & 155.08 & 0.744 & ND & 0.140 & $\mathrm{SC}$ & $\mathrm{SC}$ & $\mathrm{SC}$ \\
\hline November 1 & 184.12 & 0.898 & 0.0038 & 5.258 & 0.753 & 5.000 & 10.525 \\
\hline December 20 & 185.00 & 0.152 & 0.0018 & 10.383 & 0.605 & 9.220 & 1.316 \\
\hline Dec. 16, 1981-Dec. 20, 1982 & 1065.15 & 5.72 & 0.24 & 30.31 & 3.40 & 23.99 & 16.16 \\
\hline
\end{tabular}

ND, not detectable; SC, saimple not collected 
Table 2. Monthly nutrient concentration in the precipitation at Stavros, northeastern Greece. The mean annual concentration of each element and the relative SE are given at the boltom of each respective column

\begin{tabular}{|c|c|c|c|c|c|c|c|}
\hline \multirow[t]{2}{*}{ Collcction date } & \multirow{2}{*}{$\begin{array}{l}\text { Precipitation } \\
(\mathrm{m} m)\end{array}$} & \multicolumn{6}{|c|}{ Nutrient concentration (mg $\mathrm{f}^{-1}$ ) } \\
\hline & & $N$ & $\mathrm{P}$ & $\mathrm{Ca}$ & $\mathrm{Mg}$ & $\mathrm{Na}$ & $\mathrm{K}$ \\
\hline \multicolumn{8}{|l|}{ 1981: } \\
\hline $\begin{array}{l}\text { December } 16 \\
\text { 1982: }\end{array}$ & 20.55 & 0.209 & 0.003 & 1.14 & 0.43 & 0.72 & 0.58 \\
\hline January 19 & 123.30 & 0.240 & 0.092 & 1.24 & 0.27 & 2.80 & 0.30 \\
\hline February 11 & 26.71 & 0.768 & 0.004 & 1.53 & 0.24 & 1.07 & $\mathrm{SC}$ \\
\hline March 3 & 80.70 & 0.768 & 0.007 & 3.58 & 0.25 & 1.17 & 0.53 \\
\hline March 17 & 40.54 & 0.768 & 0.005 & 1.78 & 0.68 & 1.06 & 0.53 \\
\hline April 6 & 55.98 & 0.475 & 0.001 & 3.15 & 0.31 & 1.98 & 0.28 \\
\hline May 18 & 120.80 & 0.770 & 0.075 & 3.20 & 0.56 & 1.82 & 2.06 \\
\hline June 23 & 34.21 & 1.080 & 0.010 & 4.43 & 0.92 & 2.01 & 1.32 \\
\hline August 23 & 18.75 & 2.970 & 0.056 & 3.38 & 1.16 & 1.58 & 1.40 \\
\hline September 23 & 19.41 & 1.650 & 0.054 & 5.60 & 0.39 & 1.19 & 1.22 \\
\hline October 20 & 155.08 & 0.490 & ND & 1.88 & 1.18 & $\mathrm{SC}$ & $\mathrm{SC}$ \\
\hline November $t$ & 184.12 & 0.490 & 0.002 & 2.99 & 0.43 & 2.75 & 5.17 \\
\hline December 20 & 185.00 & 0.823 & 0.010 & 4.97 & 0.33 & 5.49 & 0.63 \\
\hline Dec. $16,1981-$ Dec. 20,1982 & 1065.15 & $\begin{array}{l}0.88 \pm 0.20 \\
(n=13)\end{array}$ & $\begin{array}{l}0.024 \pm 0.009 \\
(n=13)\end{array}$ & $\begin{array}{l}2.99 \pm 0.40 \\
(n=13)\end{array}$ & $\begin{array}{l}0.47 \pm 0.09 \\
(n=13)\end{array}$ & $\begin{array}{l}1.97 \pm 0.37 \\
(n=12)\end{array}$ & $\begin{array}{l}1.27 \pm 0.40 \\
(n=11)\end{array}$ \\
\hline
\end{tabular}

Table 3. Correlation between monthly precipitation nutrient inputs and monthly precipitation volumes. The model of tegression applied is shown in parenthesis

\begin{tabular}{|c|c|c|c|c|c|c|}
\hline \multirow[t]{2}{*}{ Correlation } & \multicolumn{6}{|c|}{ Correlation coefficient $(r)$} \\
\hline & $\mathrm{N}$ & $\mathrm{P}$ & $\mathrm{Ca}$ & $\mathrm{Mg}$ & $\mathrm{Na}$ & $\mathrm{K}$ \\
\hline Input-precipitation volume & $\begin{array}{l}0.76 \\
\text { (Linear) }\end{array}$ & $\begin{array}{l}0.38 \\
\text { (Linear) }\end{array}$ & $\begin{array}{l}0.15 \\
\text { (Multiplicative) }\end{array}$ & $\begin{array}{l}0.71 \\
\text { (Lineat) }\end{array}$ & $\begin{array}{l}0.62 \\
\text { (Exponential) }\end{array}$ & $\begin{array}{l}0.76 \\
\text { (Linear) }\end{array}$ \\
\hline
\end{tabular}

Table 4. Monthly deposition of nutrients it throughtall of Arbutus unedo (AU) and Quercus ceccifera (QC) at Stavros, northeastern Grecce

\begin{tabular}{|c|c|c|c|c|c|c|c|c|c|c|c|c|c|c|}
\hline \multirow{3}{*}{$\begin{array}{l}\text { Collection } \\
\text { dalc }\end{array}$} & \multirow{2}{*}{\multicolumn{2}{|c|}{$\begin{array}{l}\text { Throughfall } \\
(\mathrm{mm})\end{array}$}} & \multicolumn{12}{|c|}{ Nutrient deposition $\left(\mathrm{kg} \mathrm{ha}^{-1}\right)$} \\
\hline & & & \multicolumn{2}{|l|}{$\mathrm{N}$} & \multicolumn{2}{|l|}{$\mathrm{P}$} & \multicolumn{2}{|l|}{$\mathrm{Ca}$} & \multicolumn{2}{|l|}{$\mathrm{Mg}$} & \multicolumn{2}{|l|}{$\mathrm{Na}$} & \multicolumn{2}{|l|}{$\mathrm{K}$} \\
\hline & $\mathrm{AU}$ & QC & $\mathrm{AU}$ & QC & $\mathrm{AU}$ & QC & $\mathrm{AU}$ & QC & $\mathrm{AU}$ & QC & $\mathrm{AU}$ & QC & $\mathrm{AU}$ & QC \\
\hline $\begin{array}{l}\text { 1981: } \\
\text { December } 16 \\
\text { 1982: }\end{array}$ & 8.72 & 7.18 & 0.058 & 0.027 & 0.0022 & 0.0004 & 0.316 & 0.211 & 0.042 & 0.108 & 0.134 & 0.178 & 0.248 & 0.451 \\
\hline January 19 & 60.02 & 43.81 & 0.581 & 0.239 & 0.0816 & 0.0250 & 2.352 & 0.658 & 0.865 & 0.142 & 2.228 & 1.524 & 2.909 & 0.861 \\
\hline February 11 & 10.15 & 5.88 & 0.087 & 0.063 & 0.0063 & 0.0013 & 0.630 & 0.110 & 0.115 & 0.115 & 0.356 & 0.310 & 0.661 & 0.134 \\
\hline March 3 & 34.48 & 22.50 & 0.038 & 0.099 & 0.0051 & 0.0007 & 2.152 & 2.510 & 0.152 & 0.354 & 0.787 & 0.969 & 0.736 & 0.664 \\
\hline March 17 & 23.10 & 17.93 & 0.124 & 0.072 & 0.0037 & 0.0030 & 0.942 & 0.797 & 0.183 & 0.115 & 0.876 & 0.427 & 0.394 & 0.547 \\
\hline April 6 & 25.68 & 16.87 & 0.102 & 0.082 & 0.0008 & 0.0148 & 1.734 & 1.078 & 0.223 & 0.149 & 1.186 & 0.948 & 0.377 & 0.558 \\
\hline May 18 & 73.75 & 52.95 & 0.356 & 0.158 & 0.0442 & 0.0111 & 2.883 & 1.554 & 0.434 & 0.259 & 1.575 & 1.084 & 1.342 & 1.404 \\
\hline June 23 & 12.57 & 10.39 & 0.204 & 0.190 & 0.0006 & 0.0054 & 0.500 & 1.488 & 0.046 & 0.195 & 0.175 & 0.137 & 0.300 & 0.142 \\
\hline August 23 & 9.55 & 6.07 & 0.202 & 0.183 & 0.0071 & 0.0078 & 0.796 & 0.868 & 0.143 & 0.205 & 0.365 & 0.199 & 0.462 & 0.460 \\
\hline September 23 & 7.85 & 9.87 & 0.137 & ND & 0.0103 & 0.0317 & 1.019 & 1.710 & 0.063 & 0.132 & 0.141 & 0.187 & 0.273 & 0.370 \\
\hline October 20 & 71.47 & 62.20 & 0.319 & 0.449 & 0.0714 & 0.0882 & 4.306 & 3.645 & 0.379 & 0.641 & 1.591 & 1.082 & 2.626 & 2.415 \\
\hline November 1 & 113.33 & 97.50 & 0.520 & 0.721 & 0.0102 & 0.1268 & 4.487 & 1.822 & 1.163 & 2.017 & 3.733 & 2.466 & 1.917 & 3.686 \\
\hline December 20 & 6.36 & 3.68 & 0.080 & 0.093 & 0.0004 & 0.0086 & 2.100 & $\mathrm{SC}$ & 1.397 & $\mathrm{SC}$ & 6.763 & $\mathrm{SC}$ & 8.393 & $\mathrm{SC}$ \\
\hline $\begin{array}{l}\text { Dec } 16,1981- \\
\text { Dec. } 20,1982\end{array}$ & 457.03 & 356.83 & 2.81 & 2.38 & 0.140 & 0.325 & 43.12 & 16.45 & 5.21 & 4.43 & 19.91 & 9.51 & 47.65 & 11.69 \\
\hline
\end{tabular}


Table 5. Monthly nutrient concentration in throughfall underneath $A$. unedo (AU) and $Q$. coccifera (QC) at Stavros, northeastern Grecee

\begin{tabular}{|c|c|c|c|c|c|c|c|c|c|c|c|c|c|c|}
\hline \multirow{3}{*}{$\begin{array}{l}\text { Collection } \\
\text { date }\end{array}$} & \multirow{2}{*}{\multicolumn{2}{|c|}{$\begin{array}{l}\text { Throughfall } \\
\text { (mm) }\end{array}$}} & \multicolumn{12}{|c|}{ Nutrient deposition ( $\mathrm{mg} \mathrm{l}^{-1}$ ) } \\
\hline & & & \multicolumn{2}{|l|}{$N$} & \multicolumn{2}{|l|}{$\mathrm{P}$} & \multicolumn{2}{|l|}{$\mathrm{Ca}$} & \multicolumn{2}{|l|}{$\mathrm{Mg}$} & \multicolumn{2}{|l|}{$\mathrm{Na}$} & \multicolumn{2}{|l|}{$\mathrm{K}$} \\
\hline & $\mathrm{AU}$ & $\mathrm{QC}$ & $\mathrm{AU}$ & $Q C$ & AU & $\mathrm{QC}$ & $\mathrm{AU}$ & $Q C$ & $\mathrm{AU}$ & $\mathrm{QC}$ & $\mathrm{AU}$ & $\mathrm{QC}$ & $\mathrm{AU}$ & $Q C$ \\
\hline $\begin{array}{l}\text { 1981: } \\
\text { December } 16 \\
\text { 1982: }\end{array}$ & 8.72 & 7.18 & 0.661 & 0.380 & 0.025 & 0.006 & 4.11 & 2.79 & 0.51 & 1.18 & 1.72 & 3.28 & 2.90 & 6.78 \\
\hline January 19 & 60.02 & 43.81 & 0.969 & 0.546 & 0.136 & 0.057 & 4.16 & 1.49 & 1.55 & 0.33 & 3.79 & 3.68 & 4.87 & 2.01 \\
\hline February 11 & 10.15 & 5.88 & 0.855 & 1.073 & 0.062 & 0.022 & 1.58 & 3.22 & 1.10 & 1.62 & 3.39 & 5.56 & 6.30 & 2.96 \\
\hline March 3 & 34.48 & 22.50 & 0.112 & 0.441 & 0.016 & 0.003 & 6.28 & 10.87 & 0.58 & 1.39 & 2.25 & 4.91 & 1.99 & 3.41 \\
\hline March 17 & 23.10 & 17.93 & 0.537 & 0.399 & 0.016 & 0.017 & 4.20 & 4.76 & 0.78 & 0.91 & 3.70 & 1.94 & 1.79 & 3.89 \\
\hline April 6 & 25.68 & 16.87 & 0.398 & 0.487 & 0.003 & 0.088 & 7.23 & 6.51 & 0.91 & 0.92 & 4.73 & 5.69 & 1.38 & 3.15 \\
\hline May 18 & 73.75 & 52.95 & 0.483 & 0.299 & 0.006 & 0.021 & 4.00 & 2.84 & 0.58 & 0.49 & 2.07 & 2.21 & 1.80 & 2.71 \\
\hline June 23 & 12.57 & 10.39 & 1.621 & 1.823 & 0.005 & 0.052 & 8.12 & 15.72 & 0.75 & 2.06 & 2.85 & 3.06 & 4.87 & 1.50 \\
\hline August 23 & 9.55 & 6.07 & 2.113 & 3.008 & 0.074 & 0.128 & 8.08 & 12.87 & 1.53 & 0.37 & 4.03 & 2.97 & 4.98 & 5.05 \\
\hline September 23 & 7.85 & 9.87 & 1.749 & ND & 0.132 & 0.481 & 10.57 & 17.29 & 0.98 & 1.34 & 1.49 & 1.89 & 3.00 & 3.74 \\
\hline October 20 & 71.47 & 62.20 & 0.447 & 0.739 & 0.010 & 0.145 & 5.78 & 6.40 & 0.53 & 1.18 & 2.19 & 2.23 & 2.77 & 4.53 \\
\hline November 1 & 113.33 & 97.50 & 0.459 & 0.739 & 0.009 & 0.130 & 6.54 & 2.28 & 1.06 & 1.82 & 3.31 & 4.12 & 1.94 & 3.47 \\
\hline December 20 & 6.36 & 3.68 & 1.258 & 2.530 & 0.006 & 0.233 & 16.24 & 4.97 & 1.08 & 0.33 & 5.23 & $\mathrm{SC}$ & 6.49 & 0.63 \\
\hline $\begin{array}{l}\text { Dec. } 16,1981- \\
\text { Dec. } 20,1982\end{array}$ & 457.03 & 356.83 & $\begin{array}{l}0.897 \\
\pm \\
0.17\end{array}$ & $\begin{array}{l}0.958 \\
\pm \\
0.25\end{array}$ & $\begin{array}{l}0.038 \\
\pm \\
0.01\end{array}$ & $\begin{array}{l}0.106 \\
\pm \\
0.04\end{array}$ & $\begin{array}{l}6.68 \\
\pm \\
1.02\end{array}$ & $\begin{array}{l}7.25 \\
\pm \\
1.60\end{array}$ & $\begin{array}{l}0.92 \\
\pm \\
0.10\end{array}$ & $\begin{array}{l}1.13 \\
\pm \\
0.16\end{array}$ & $\begin{array}{l}3.13 \\
\pm \\
0.32\end{array}$ & $\begin{array}{l}3.46 \\
\pm \\
0.39\end{array}$ & $\begin{array}{l}3.47 \\
\pm \\
0.50\end{array}$ & $\begin{array}{l}3.60 \\
\pm \\
0.40\end{array}$ \\
\hline & & & & & & & & & $=13)$ & & & & & \\
\hline
\end{tabular}

Table 6. Correlation between monthly throughfall nutrient inputs and monthly throughfall volumes for $A$. unedo (AU) and $Q$. coccifera $(\mathrm{QC})$

\begin{tabular}{|c|c|c|c|c|c|c|}
\hline \multirow[t]{2}{*}{ Correlation } & \multicolumn{6}{|c|}{ Correlation coefficient $(r)$} \\
\hline & $N$ & $\mathrm{P}$ & $\mathrm{Ca}$ & $\mathrm{Mg}$ & $\mathrm{Na}$ & $\mathrm{K}$ \\
\hline \multirow[t]{2}{*}{ Input-throughfall volume } & $\begin{array}{l}\text { (AU) } 0.80 \\
\text { (Linear) }\end{array}$ & $\begin{array}{l}0.48 \\
\text { (Exponential) }\end{array}$ & $\begin{array}{l}-0.57 \\
\text { (Reciprocal) }\end{array}$ & $\begin{array}{l}0.63 \\
\text { (Exponential) }\end{array}$ & $\begin{array}{l}0.44 \\
\text { (Exponential) }\end{array}$ & $\begin{array}{l}-0.65 \\
\text { (Reciprocal) }\end{array}$ \\
\hline & $\begin{array}{l}\text { (QC) } 0.83 \\
\text { (Linear) }\end{array}$ & $\begin{array}{l}0.79 \\
\text { (Linear) }\end{array}$ & $\begin{array}{c}0.57 \\
\text { (Linear) }\end{array}$ & $\begin{array}{l}0.82 \\
\text { (Exponential) }\end{array}$ & $\begin{array}{l}-0.75 \\
\text { (Reciprocal) }\end{array}$ & $\begin{array}{c}0.90 \\
\text { (Linear) }\end{array}$ \\
\hline
\end{tabular}

Table 7. Ratios of throughfall to bulk precipitation inputs based on the mean monthly values of the relative nutrients

\begin{tabular}{lllllll}
\hline Species & \multicolumn{5}{l}{$\begin{array}{l}\text { Throughfall/precipitation ratio } \\
\text { (based on } \text { mg }^{-1} \text { ) }\end{array}$} \\
\cline { 2 - 7 } & $\mathrm{N}$ & $\mathrm{P}$ & $\mathrm{Ca}$ & $\mathrm{Mg}$ & $\mathrm{Na}$ & $\mathrm{K}$ \\
\hline Arbutus unedo & 1.02 & 1.58 & 2.23 & 1.96 & 1.59 & 2.73 \\
Quercus coccifera & 1.09 & 4.42 & 2.42 & 2.40 & 1.76 & 2.83 \\
Mean & 1.05 & 3.00 & 2.32 & 2.18 & 1.67 & 2.78 \\
\hline
\end{tabular}

element finally deposited on the ground underneath the canopy will be lower. There was a tight correlation between monthly nutrient inputs in throughfall with monthly throughfall volumes for most of the nutrients (Table 6).
Table 8. Ratios of throughfall to bulk precipitation inputs based on annual values of the relative nutrients

\begin{tabular}{llllllll}
\hline Species & \multicolumn{6}{l}{$\begin{array}{l}\text { Throughfall/precipitation ratio } \\
\text { (based on } \mathrm{kg} \mathrm{ha}^{-1} \text { year }^{-1} \text { ) }\end{array}$} \\
\cline { 2 - 7 } & $\mathrm{N}$ & $\mathrm{P}$ & $\mathrm{Ca}$ & $\mathrm{Mg}$ & $\mathrm{Na}$ & $\mathrm{K}$ \\
\hline Arbutus unedo & 0.49 & 0.58 & 1.42 & 1.53 & 0.83 & 2.95 \\
Quercus coccifera & 0.42 & 1.35 & 0.54 & 1.30 & 0.40 & 0.72 \\
Mean & 0.45 & 0.96 & 0.98 & 0.41 & 0.61 & 1.83 \\
\hline
\end{tabular}

\section{Discussion}

The location of mediterranean-type ecosystems near the coast of the continents means that these systems are subject to relatively high deposition 
Table 9. Annual atmospheric nutrient deposition in bulk precipitation in several ecosystems

\begin{tabular}{|c|c|c|c|c|c|c|c|c|}
\hline \multirow[t]{2}{*}{ Locale and reference } & \multirow{2}{*}{$\begin{array}{l}\text { Annual } \\
\text { precipitation } \\
(\mathrm{mm})\end{array}$} & \multirow{2}{*}{$\begin{array}{l}\text { Distance } \\
\text { from the sea } \\
\text { (ka) }\end{array}$} & \multicolumn{6}{|c|}{ Nutricnt deposition $\left(\mathrm{kg} \mathrm{hal}^{-1}\right.$ ycar $\left.^{-1}\right)$} \\
\hline & & & $N$ & $P$ & $\mathrm{Ca}$ & $\mathrm{Mg}$ & $\mathrm{Na}$ & $\mathrm{K}$ \\
\hline \multicolumn{9}{|l|}{ Meditertanean-type ecosystems: } \\
\hline $\begin{array}{l}\text { California chaparral } \\
\text { (Schlesinger and Hasey 1980) }\end{array}$ & $450-770$ & $5-10$ & 1.00 & - & 1.40 & 0.80 & 6.10 & 0.40 \\
\hline $\begin{array}{l}\text { California chaparral } \\
\text { (Schlesinget et ai. 1982) }\end{array}$ & 756 & 10 & 1.50 & - & 1.90 & 1.00 & - & 0.60 \\
\hline $\begin{array}{l}\text { California coastal scrub } \\
\text { (Clayion 1972) }\end{array}$ & 635 & 2 & - & - & 7.60 & 3.80 & 68.60 & 14.90 \\
\hline $\begin{array}{l}\text { France garrigue } \\
\text { (Lossaint and Rapp 1971; Lossaint 1973) }\end{array}$ & 770 & 20 & 14.60 & 1.00 & 10.50 & 1.50 & 22.60 & 2.00 \\
\hline $\begin{array}{l}\text { Soutl Australia eucalyptus open forest } \\
\text { (Guthrie et al. 1978) }\end{array}$ & 1295 & $?$ & - & - & 1.27 & 1.40 & 17.93 & 4.20 \\
\hline $\begin{array}{l}\text { South Africa coastal fynbos } \\
\text { (Brown et al. 1984) }\end{array}$ & 381 & $?$ & - & 0.19 & - & - & - & - \\
\hline $\begin{array}{l}\text { Northeast Greece maquis } \\
\text { (Present study) }\end{array}$ & 1065 & $<1$ & 5.72 & 0.24 & 30.31 & 3.40 & 23.99 & 16.60 \\
\hline \multicolumn{9}{|l|}{ Other forests: } \\
\hline $\begin{array}{l}\text { Oregon coniferous forest } \\
\text { (Tatrant el al. 1968) }\end{array}$ & 2286 & 10 & 1.50 & - & - & - & - & -- \\
\hline $\begin{array}{l}\text { New Hampshire temperate forest } \\
\text { (Likens et al. 1977) }\end{array}$ & 1250 & 116 & 20.70 & 0.04 & 2.20 & 0.60 & 1.60 & 0.90 \\
\hline
\end{tabular}

of ions such as sodium, which are plentiful in seawater (Junge 1963; Art et al. 1974). In the present study, approximately $24 \mathrm{~kg} \mathrm{ha}^{-1}$ of sodium werc deposited annually, indicating the relative importance of the sea as a source of this element. There is considerable evidence that magnesium is also derived from marine sources (Schlesinger and Hasey 1980). Our data show that $3.4 \mathrm{~kg} \mathrm{ha}^{-1}$ were deposited annually on the site. The values given in the bibliography for several mediterranean-type ecosystems vary from $0.80 \mathrm{~kg} \mathrm{ha}^{-1}$ for a Californian chaparral (Schlesinger and Hasey 1980) to $3.80 \mathrm{~kg} \mathrm{ha}^{-1}$ for a coastal scrub community (Clayton 1972) (Table 9). The value observed for our site is closer to that for the coastal shrub community than to that for the chaparral and the reason probably is that both sites are typically "coastal".

Although calcium and potassium may also be derived from maritime sources, their amount in the precipitation comes mainly from clay minerals in soil dust and increases with continental influence (Gorham 1961). A high amount of these two nutrients was deposited at the Stavros site $(30.31$ and $16.60 \mathrm{~kg} \mathrm{ha}^{-1}$ for calcium and potassium, respectively). Whether or not these amounts were of maritime origin cannot be directly answered by using the data on hand. However, we can postulate that during the year of this study there was no dry peri- od long enough to be considered a period of drought (Fig. 1) that could be sufficient to cause complete drying of the surface soil so as to render it erodible by wind. Furthermore most of the ground is covered by litter, so that it is not directly subjected to wind erosion. Therefore it is reasonable to hypothesize that most of these elcments derive from seawater.

Published data for other mediterranean-type ecosystems of the world give various values of nutrient deposition (Table 9). Although the amount of potassium deposited in the 1-year study at Stavros is quite similar to that deposited at the coastal scrub community of California $(16.60)$ and $14.90 \mathrm{~kg} \mathrm{ha}^{-1}$, respectively), calcium deposition is much higher $\left(30.31\right.$ versus $\left.7.60 \mathrm{~kg} \mathrm{ha}^{-1}\right)$. The value for annual nitrogen deposition may be considered high $\left(5.72 \mathrm{~kg} \mathrm{ha}^{-1}\right.$, and is much higher than the amount reported for Californian chaparral (cited in Table 9: Schlesinger and Hasey 1980; Schlesinger et al. 1982) but lower than that of the French maquis (also cited in Table 9: Lossaint and Rapp 1971; Lossaint 1973). Although there is some evidence that much of the nitrate nitrogen in bulk precipitation in southern California may also be derived from soil dust (Schlesinger and Hasey 1980), no such evidence is avalable for the French garrigue or for the Greek maquis mostly 
because of lack of data on dry deposition. Considering that the available soil phosphorus at the Stavros site is very low $0.0011 \%$ for the top $2 \mathrm{~cm}$ and $0.00033 \%$ for the lower $2-20 \mathrm{~cm}$ (Arianoutsou and Paraskevopoulos, unpublished data), the deposition of $0.24 \mathrm{~kg} \mathrm{ha}^{-1}$ of phosphorus by rainfall is rather important. Brown et al. (1984) estimated that $4.5 \%$ of the soluble soil phosphorus of a coastal fynbos ecosystem originates from precipitation, by which $0.19 \mathrm{~kg} \mathrm{ha}^{-1}$ of phosphorus are annually deposited on the ecosystem (Table 9).

Chemical analysis of throughfall showed enrichment for all the nutrients studied, as water passes through the canopy (Tables 5,7 ). It has been shown (Attiwill 1966; Nihlgard and Lindgren 1977) that the major source of enrichment is foliar leaching. Quantities of all the nutrients reaching the soil surface will not be increased because of the lower water volume containing an otherwise increased nutrient concentration. Other investigators have observed similar chemical changes in throughfall compared to precipitation (Guthrie et al. 1978; Rolfe et al. 1978; Carlisle et al. 1966). Some of these chemical fluxes can be attributed to leaching from plant tissue. For example, the presence of sodium and potassium in the cell sap accounts for their being leached readily by rainwater. Guthrie et al. (1978) found that foliar leaching accounts for $66 \%$ of the total return of sodium from biomass to soil and for $56 \%$ of the total return of potassium. Additions of nutrients by foliar leaching should not be considered as being directly of atmospheric origin, but only indirectly, since leaching would not happen without rain.

The nutrient cycling processes in any ecosystem, namely (i) the geochemical cycles of import to and export from the ecosystem (precipitation, dry deposition, stream (low), (ii) the biogeochemical cycles between plant and soil within the ecosystem (decomposition, leaching) and (iii) the biochemical cycles of internal transfer within the biomass (Switzer and Nelson 1972) define the vigour and the stability of the ecosystem. The balance between the inputs of nutrients to any ecosystem in rainwater and the output of nutrients from the ecosystem will define its productivity, and furthermore will be the basis for any management plan for that ecosystem. The evergreen sclerophyllous ecosystems of Greece, known as maquis, are threatened from fire and overgrazing. The result of both fire and overgrazing are one of the causes of considerable nutrient losses (Arianoutsou-Faraggitaki and Margaris 1981, 1982; Arianoutsou-Faraggitaki 1985). The understanding of the phenomena mentioned above as a source of nutrients in the medi- terranean-type ecosystems (not only in Greece) is therefore of major importance and needs further investigation.

Acknowledgements. I an grateful to Dr. S. Tselas and $\mathrm{Mr}$, L. Loukas for their help in the analytical work. I would like also to express my thanks to Mr. Th.A. Mardiris and Dr. D. Alifrangis for their help in the atomic absorption spectroscopy. Editorial assistance was gencrously provided by Prof, P.A. Gerakis; Ms. A. Karamanli-Vlahopoulou prepared the manuscript. The work would not have been possible without the encouragement and understanding of my companion.

\section{References}

Arianoutsou $M$ (1989) Timing of litter production in a maquis ecosystem of North-Eastern Greece. Acta Occol (in press)

Arianoutsolt-Faraggitaki $M$ (1985) Desertificalion in Grece: the case of Lesvos island. J Arid Environ 9:237-242

Arianoutsou-Faraggitaki M, Margaris NS (1981) Firc-induced nutrient losses in a phryganic ecosystem. Int I Biometcorol $25: 341-347$

Arianoutsou-Faraggitaki M, Margaris NS (1982) Phryganic (East Mediterrancan) ecosystems and fire. Ecol Medil $8: 473-480$

Art HW, Bormann FI, Voigt GK, Woodwell GM (1974) Barrier island forest ccosystem: Role of meleorologic nutrient imputs. Science 184:60-62

Attiwil] PM (1966) The chemical composition of rain-water in relation to cycling of nutrients in mature fitcalyptus forest. Plant Soil $24: 390-406$

Bomann FFI, Likens GS (1967) Nutrient cycling. Science 155:424-429

Brown G, Mitchell DT, Stock WD (1984) Atmospheric deposition of phosphorus in a coastal ecosystem of the SouthWestern Cape, South Africa. J Ecol 72:547-55t

Carlisle A, Brown AIJF, White EJ (1966) The organic malter and nutrient elements in the precipitation beneath a sessile oak ( Querctus petraca) canopy. J Fcol 54:87-98

Clayton JL (1972) Salt spray and mineral cycling in 1 wo Callifornian coistal ccosystems. Ecology $53: 7481$

Feller MC (1981) Catchment nutrient budgets and geological weathering in Eucalyphos regnans ecosystems in Victoria. Austr J ticol 6:65-77

Gorham E (1961) Factors infuencing supply of major ions to inland waters, with special reference to the atmosphere. Bull Geol Soc Amer 72:795-840

Guthrie HB, Altiwill PM, Leuning R (1978) Nutrient cycling in a Eucdlyphus ohligua (L'Hérit.) Forest. 11. A study in a sinall catchment. Austr J Bot 26:189-201

Junge CE (1963) Air chemistry and radionctivity. Academic Prese, New York

Likens GE, Bormann FH, Picrce RS, Ealton JS, Johnson NN (1977) Biogeochemistry of a Corest ecosystem. Springer, New York

Lossaint $\mathrm{b}^{3}$ (1973) Soil-vegetation relationships in medilctraneun ecosysicms of southern France. In: di Castri $F$. Mooney HA (eds). Mediterranean-type ecosystems: Origin and structure. Springer, New York, pp 199-210

Lossaint P, Rapp M (1971) Repartition de lat matière organique, productivité et cycles des elements mineraux dans des écosystèmes de climal méditerrancen. In: Duvigneaud P (cd), Productivity of rorest ecosystems. UNESCO, Paris, pp 597617 
Nihlgard and Lindgren (1977) Plant biomass, primary production and bioclements of three mature beecl forests in south Sweden. Oilos 28:95-104

Rolfe GL, Akhtar MA, Arnold LE (1978) Nutrient fluxes in precipitalion throughfall and stemflow in an oak-hickory Corest of southern Illionis. Agric Experim Stn For Res Rep, 78. Univ of Illinois, Urbana, Illinois

Rundel PW (1979) Ecologict impact of fires on mincral and sediments pools and fuxes. In: Agec JK (ed) Fire and fuel management in mediterranean-climate ecosystems: Research prioritics and Programmes. MAB Tech Note 11, UNESCO. Paris, pp 17-21

Sclilesinger WH, Hasey MM (1980) The nutrient content of precipitation, dry falloul, and intercepted acrosols in the chaparral of southern Californiat. Am Midl Nat 103: 114-122

Schlesinger WH, Gray JT, Gilliam FS (1982) Atmospheric deposition processes and their importance as sources of nu- trients in a chaparral ecosystcm of Southern California. Waler Resour Res 18:623-629

Switzer GL, Ncison LE (1972) Nutricnt accumulation alds cycling in Loblolly pine (Pinus taeda L.) plantation ccosystems: the first twenty years. Soil Sci Soc Am Proc $36: 143-147$

Tamin CO (1958) The atmosphere. Handb Pflanzenphysiol $6: 233-242$

Tarrant RF, Lu KC, Chen CS, Bollen WB (1968) Nitrogen content of precipitation in a constal Oregon forest opening. Tellus 20:554-556

Varley JA (1966) Automatic method for the determination of nitrogen, phosphorus and polassium in plant material. Analyst $91: 119-126$

Received July 6, 1988; revised February 6, 1989 Accepted February 17, 1989 